\author{
УДК 347.941 \\ DOI https://doi.org/10.32840/pdu.2-1.10
}

O. I. Лук'янчук

аспірант кафедри цивільного права і процесу Національної академії внутрішніх справ

\title{
ПІКЛУВАННЯ ПРО НЕПРАЦЕЗДАТНИХ, НЕМІЧНИХ БАТЬКІВ: ЗАКОНОДАВЧЕ ЗАКРІПЛЕННЯ МОРАЛЬНОГО ОБОВ'ЯЗКУ
}

Метою даного дослідження $\epsilon$ винайдення шляхів для реального застосування на практиці норми, що закріплює обов'язок дітей піклуватися про батьків. Для досягнення вказаної мети вирішенню підлягають такі задачі: встановлення сутності обов'язку дітей піклуватися про батьків, визначення його особливостей, з'ясування обставин та умов, за яких у батьків виникає право стягнення коштів на покриття витрат, пов'язаних 3 наданням піклування. У статті здійснено аналіз змісту обов'язку дитини, повнолітніх дочки та сина піклуватися про своїх батьків. Проведено аналіз передумов, що сприяли законодавчому закріпленню даного обов'язку. Встановлено коло осіб, зобов'язаних піклуватися про батьків. Надано правову характеристику завдяки системному аналізу законодавства, запропоновано юридичне визначення стану «немічності». Встановлено, що стан немічності за своїми ознаками співпадає з ознаками безпорадного стану. Обґрунтовано необхідність на законодавчому рівні закріпити визначення стану немічності, який, в свою чергу, відповідає ознакам непрацездатності. 3'ясовано, що теоретично батьки можуть перебувати в будинках інвалідів, будинках для осіб похилого віку, закладах охорони здоров'я або інших державних чи громадських закладах. Якщо повнолітні діти не беруть участі в утриманні своїх батьків, влаштованих до цих закладів, то останні мають право подати позов до суду про стягнення аліментів на батьків у примусовому порядку. Встановлено відмінність між покладеним на дітей обов'язком піклуватися про своїх батьків (ст. 172 СК України), обов'язком повнолітніх дочки, сина брати участь у додаткових витратах на батьків, викликаних тяжкою хворобою, інвалідністю або немічністю (ст. 203 СК України) та правом батьків, які є тяжко хворими або особами з інвалідністю стягнути з дитини (неповнолітньої), дочки, сина одноразово або протягом певного строку коштів, на покриття витрат, пов'язаних з їх лікуванням та доглядом (ст. 206 СК України). Визначено підстави, за яких у батьків виникає право на стягнення за рішенням суду коштів, на покриття витрат, пов'язаних з наданням їм такого піклування третіми особами. Окремо зосереджено увагу на інституті законного представництва, оскільки повнолітні дочка та син наділені правом звернутися за захистом прав та інтересів непрацездатних, немічних батьків як їх законні представники, без спеціальних на те повноважень.

Ключові слова: обов'язок піклуватися, піклування, турбота, догляд, допомога, непрацездатні, безпорадний стан, немічність, немічна особа, законне похилий вік, покриття витрат, тяжка хвороба, каліцтво, представництво, стягнення коштів, утримання, аліменти.

Постановка проблеми. Обов'язок повнолітніх дітей піклуватися про своїх непрацездатних батьків закріплений в ст. 51 Конституції України [1]. Не можна не погодитись із думкою про те, що дана норма видається більше моральним обов'язком аніж юридичним, однак таке враження складається лише на перший погляд, адже дана конституційна

(c) Лук'янчук О. I., 2019 норма знайшла своє відображення в нормах Сімейного кодексу України [2] і саме в них він більш деталізований, зокрема в ст. 172, відповідно до якої, - дитина, повнолітні дочка, син зобов'язані піклуватися про батьків, проявляти про них турботу та надавати їм допомогу. Якщо ж повнолітні дочка, син не піклуються про своїх непрацездатних, немічних батьків, настає відповідальність - з них можуть бути за рішенням суду стягнуті кошти на покриття витрат, пов'язаних із надан- 
ням такого піклування. Отже закріплення обов'язку піклування на законодавчому рівні $\epsilon$, проте, нажаль, через термінологічну невизначеність та колізію із нормами інших галузей права, взагалі стоїть під питанням його дієвість на практиці. По-перше, не визначено поняття «немічність», адже немічні не завжди $€$ непрацездатними, а отже не маючи чіткого розуміння, що означає стан немічності, зацікавлена особа може не розуміти, які саме докази їй належить надати суду для підтвердження цього стану. По-друге, необхідно розібратися в чому саме виражається піклування за непрацездатними, немічними батьками для розуміння обґрунтованості своїх вимог у разі звернення батьків до суду із позовом до своїх дітей щодо стягнення коштів на покриття витрат, пов'язаних із наданням такого піклування.

Тому у статті зосередимо увагу на дискусійних питаннях, що стосуються даного обов'язку та окремо зупинимося на закріпленому у СК України праві повнолітніх дочки, сина звернення за захистом прав та інтересів непрацездатних, немічних батьків як їх законних представників без спеціальних на те повноважень, тому що нині ці питання набувають актуальності, однак залишаються відкритими, оскільки не знайшли свого остаточного вирішення.

Отже, актуальність теми цього дослідження, обумовлена потребою вирішення питання щодо вдосконалення правового регулювання обов'язку дітей піклуватися про батьків.

Стан дослідження. У науці сімейного права особисті немайнові відносини батьків і дітей були предметом дослідження багатьох науковців, таких як: Л. М. Баранова, В. І. Борисова, В. С. Гопанчук, М. М. Дякович, I. В. Жилінкова, О. Ю. Косова, Л В Красицька, В. А. Кройтор, 3. В. Ромовська, О. Й. Пергамент, л. В. Сапейко та інших.

Аналіз праць цих науковців забезпечив можливості сформулювати підґрунтя для виконання завдань та цілей даного дослідження, однак, описана вище проблематика обов'язку дітей піклуватися про своїх батьків раніше не була комплексно дослі- джена, що і спонукало до її висвітлення у цій статті.

Мета і задачі статті. Метою даного дослідження $\epsilon$ винайдення шляхів для реального застосування на практиці норми, що закріплює обов'язок дітей піклуватися про батьків. Для досягнення вказаної мети вирішенню підлягають такі задачі: встановлення сутності обов'язку дітей піклуватися про батьків, визначення його особливостей, з'ясування обставин та умов, за яких у батьків виникає право стягнення коштів на покриття витрат, пов'язаних з наданням піклування.

\section{Виклад основного матеріалу.} Сімейне законодавство України, а саме частина 1 статті 172 СК України покладає обов'язок на дитину, повнолітніх дочку та сина піклуватися про батьків, проявляти про них турботу та надавати їм допомогу [2].

Якщо зазирнути в історію правового регулювання цього обов'язку, то треба зазначити, що Розділ 2 Кодексу 1926 року мав назву «Особисті права та обов'язки дітей та батьків», але не містив жодного обов'язку дітей щодо батьків.

Згідно з статтею 58 Кодексу 1969 року, батьки та діти зобов'язані були «подавати» взаємну моральну підтримку. Кодекс не містив жодних застережень щодо віку та стану здоров'я батьків чи дітей. Отже можна зробити висновок, що це була стандартна модель поведінки як батьків, так і дітей по відношенню один до одного. Частина 1 статті 81 цього ж кодексу зобов'язувала дітей піклуватися про батьків та надавати їм допомогу.

Конституція Української РСР 1978 року у статті 64 зобов'язувала дітей піклуватися про батьків і надавати їм допомогу. Цей конституційний обов'язок не пов'язувався із повноліттям дітей [3, с. 263].

Конституція України 1996 року цей обов'язок закріпила лише за повнолітніми дітьми.

Автор СК України, 3. В. Ромовська, піддає критиці таке конституційне вирішення проблеми, адже, на її думку, християнський канон: «шануй батька і матір свою» - має бути визначальним при формуванні правового забезпечення особистої сфери відносин між дитиною та ії 
батьками. Відповідно до цього у частині 1 статті 172 СК розширено не лише зміст конституційного обов'язку, а й коло його носіїв [2].

Виконання обов'язку піклуватися про батьків та надавати їм допомогу не завжди пов'язане із грошовими витратами. Допомога може бути надана матері, батькові у виконані певної хатньої роботи, роботи на городі, прибудинковій території. Батькам-інвалідам може бути потрібна інша допомога, викликана каліцтвом, тяжкою хворобою [3, с. 264]. 3 цим не можна не погодитись, адже в силу поступового зростання така допомога батькам по силі і дитині.

Відповідно до ч. 2 ст. 172 СК України [2], задля реалізації обов'язку піклуватися про батьків, повнолітні дочка, син наділені правом звернутися за захистом прав та інтересів непрацездатних, немічних батьків як їх законні представники, без спеціальних на те повноважень. Але що стосується захисту прав та інтересів батьків у суді, то і ЦПК України, і КПК України містять перелік осіб, які можуть приймати участь у судовому засіданні в якості законних представників, а також тих осіб, які можуть мати законного представника. Під їх перелік представництво непрацездатних або немічних батьків повнолітніми дітьми не передбачено. Тому, варто було 6 внести необхідні зміни, що регулюють процесуальне законодавство для врегулювання даного питання та уникнення його подвійного тлумачення.

Частина 3 ст. 172 СК України встановлює, що якщо повнолітні дочка, син не піклуються про своїх непрацездатних, немічних батьків, з них можуть бути за рішенням суду стягнуті кошти на покриття витрат, пов'язаних із наданням такого піклування [2].

Отже, робимо висновок, що відповідальність за непіклування та ненадання допомоги батькам виникає не завжди, для цього $€$ певні умови: обов'язок щодо покриття витрат, пов'язаних із наданням такого піклування лежить лише на повнолітніх дітях; батьки мають бути непрацездатними, немічними.

Згідно чинного законодавства непрацездатність пов'язується $з$ пенсійним віком або з інвалідністю.
Відповідно до п. 6) ч. 3 ст. 37 Закону України «Про загальнообов'язкове державне пенсійне страхування» [4], до непрацездатних членів сім'ї закон відносить зокрема батька, матір, якщо вони $\epsilon$ інвалідами або досягли пенсійного віку, встановленого статтею 26 цього ж закону.

Відповідно до Закону України «Про прожитковий мінімум» [5], до осіб, які втратили працездатність, відносяться: 1) особи, які досягли встановленого законом пенсійного віку; 2) особи, які досягли пенсійного віку, що дає право на призначення пенсії на пільгових умовах; 3) непрацюючі особи, визнані особами з інвалідністю в установленому порядку.

Ще одне тлумачення непрацездатної особи в контексті права на утримання одного з подружжя іншим надається у ст. 75 СК України - непрацездатним вважається той із подружжя, який досяг пенсійного віку, встановленого законом, або $€$ особою з інвалідністю I, II чи III групи [2].

Відповідно до Закону України «Про реабілітацію осіб з інвалідністю в Україні» [6], інвалідність - це міра втрати здоров'я у зв'язку із захворюванням, травмою (ії наслідками) або вродженими вадами, що при взаємодії із зовнішнім середовищем може призводити до обмеження життєдіяльності особи, внаслідок чого держава зобов'язана створити умови для реалізації нею прав нарівні з іншими громадянами та забезпечити ії соціальний захист.

Втрата здоров'я - наявність хвороб і фізичних дефектів, які призводять до фізичного, душевного і соціального неблагополуччя.

Обмеження життєдіяльності - помірно виражена, виражена або значно виражена втрата особою внаслідок захворювання, травми (ії наслідків) або вроджених вад здатності до самообслуговування, пересування, орієнтації, контролю своєї поведінки, спілкування, навчання, виконання трудової діяльності нарівні з іншими громадянами.

Особа з інвалідністю - це особа зі стійким розладом функцій організму, що при взаємодії із зовнішнім середовищем може призводити до обмеження ії життєдіяль- 
ності, внаслідок чого держава зобов'язана створити умови для реалізації нею прав нарівні з іншими громадянами та забезпечити її соціальний захист.

В свою чергу, п. 13 та п. 16 ч. 1 ст. Закону України «Про зайнятість населення» [7] надано визначення поняттю «працездатна особа», відповідно до якого - це особа віком від 16 років, яка не досягла встановленого статтею 26 Закону України "Про загальнообов'язкове державне пенсійне страхування" пенсійного віку та проживає на території України і за станом здоров'я здатна до активної трудової діяльності.

Хочемо звернути увагу, що за цим законом, законодавець пропонує «поставити під питання» працездатність особи, яка за станом здоров'я не здатна до активної трудової діяльності. Однозначно, під дану категорію осіб можемо віднести осіб з інвалідністю та осіб, які ще не досягли пенсійного віку, їм не встановлена в законному порядку група інвалідності, однак в силу, приміром, тяжкої хвороби або каліцтва вони не здатні до активної трудової діяльності.

В той же час Закон України «Про прожитковий мінімум» до працездатних осіб відносить осіб, які не досягли встановленого законом пенсійного віку [5].

Однозначно тлумачення працездатної особи, подане в першому варіанті, а саме у Законі України «Про зайнятість населення» [7] більш змістовніше відображає дане поняття.

Тобто, має сенс розглядати два поняття «непрацездатна особа» та «працездатна особа» у сукупності. 3 норм законодавства випливає, що особи, які здатні до трудової діяльності $€$ працездатними, а особи, які в силу різноманітних причин втратили таку здатність - можуть визнаватися непрацездатними. В даному випадку на думку спадають такі юридичні категорії як «немічність» або «безпорадний стан». На сьогоднішній день тлумачення поняття немічності відсутнє в законодавстві, а от щодо безпорадного стану, то відповідно до п. 6 Постанови Пленуму Верховного Суду України «Про судову практику у справах про спадкування», безпорадним слід розуміти стан особи, зумовлений похилим віком, тяжкою хворобою або каліцтвом, коли вона не може самостійно забезпечувати умови свого життя, потребує стороннього догляду, допомоги та піклування [8].

Відповідно до Закону України «Про основні засади соціального захисту ветеранів праці та інших громадян похилого віку в Україні», громадянами похилого віку визнаються особи, які досягли пенсійного віку, а також особи, яким до досягнення зазначеного пенсійного віку залишилося не більш як півтора року [9] .

Отже, можна зробити висновок, що особа, яка не досягла пенсійного віку та не має юридично встановленого статусу особи з інвалідністю, в той же час, перебуваючи в безпорадному стані, зумовленого похилим віком, тяжкою хворобою або каліцтвом - однозначно не може вважатися працездатною.

Що ж до поняття немічності, то український тлумачний словник подає нам таке тлумачення даного слова: 1) слабий, безсилий, втратив силу через хворобу; 2) неспроможний, нездатний зробити що-небудь, впоратися самотужки з чимось; безпорадний.

Науково-практичний коментар Сімейного кодексу України роз'яснює, що непрацездатні не завжди $\epsilon$ немічними. А немічними можуть вважатися й ті, що ще не досягли пенсійного віку, не визнані ще інвалідами, але через каліцтво або хворобу не мають достатніх фізичних сил для самостійного звернення за захистом [3, с. 264].

Отже, виходячи з такого тлумачення поняття «немічності» робимо висновок, що такий стан за своїми ознаками співпадає з ознаками безпорадного стану, тож нами пропонується надати визначення стану немічності як такого, що зумовлений похилим віком, тяжкою хворобою або каліцтвом. В свою чергу, на нашу думку, доцільно було 6 надати законодавче тлумачення поняттю «немічний», доповнити частину 2 ст. 172 СК України другим абзацом: «Немічною вважається особа, яка в силу свого похилого віку, тяжкої хвороби або каліцтва, не може самостійно забезпечувати умови свого життя, потребує стороннього догляду, допомоги та піклування.». 
ВC за розглядом цивільної справи № 200/21452/15-ц у своїй постанові від 17.10.2018 вказав, що безпорадний стан необхідно доказувати відповідними записами в медичних документах. Отже аналогічно і стан немічності, на нашу думку, може підтверджуватися відповідними записами в медичних документах. Для прикладу, можна привести рішення касаційної інстанції у цивільній справі № 6-24306св12 в якій стан немічності батька дочка довела копією медичної книги свого батька, з якої вбачається, що лікарем неврологом в нього виявлено порушення мозкового кровообігу в коркових гілках правої сторони, моторна афазія, аграфія, крім того з наявного у матеріалах справи висновку ЛКК вбачається, що у батька також відсутня мова, порушено функцію писемності [10].

На практиці необхідно розрізняти відмінність зобов'язання за ч. 3 ст. 172 СК України та ст. 203 СК України [2]. Обов'язок піклування та догляду за немічними батьками носить особистий немайновий характер, в той час як обов'язок брати участь у додаткових витратах на батьків, викликаних тяжкою хворобою, інвалідністю або немічністю полягає в понесенні витрат за товари і послуги, що носять матеріальний характер, зокрема на придбання ліків, проведення операційного втручання, встановлення протезів, спеціальних послуг з транспортування та перевезення хворих, послуги медичної сестри та санітарки).

Теоретично батьки можуть перебувати в будинках інвалідів, будинках для осіб похилого віку, закладах охорони здоров'я або інших державних чи громадських закладах.

3 огляду на закордонний досвід, в даному випадку вищезазначені заклади можуть виступають законними представниками батьків. Якщо повнолітні діти не беруть участі в утриманні своїх батьків, влаштованих до цих закладів, то останні мають право подати позов до суду про стягнення аліментів на батьків у примусовому порядку. Присуджені судом кошти на утримання батьків можуть перераховуватися, наприклад, на їх особистий банківський рахунок.
Отже, у частині 3 статті 172 СК України законодавчо закріплене право, яке було вироблене практикою і відображено теоретичну догму: обов'язок особистого немайнового характеру, насамперед обов'язок щодо піклування не може забезпечуватися можливістю його примусового виконання. У зв'язку з цим, єдине, на що можуть розраховувати похилі батьки, яких не відвідують роками діти, так це на присудження, крім аліментів, додаткової грошової суми для оплати послуг того, хто піклувався про них [3, с. 264].

\section{Список використаної літератури:}

1. Конституція України від 28.06.1996 року № 254к/96-ВР [Електронний ресурс] Режим доступу до ресурсу: https:// zakon.rada.gov.ua/laws/show/254к/96-вр.

2. Сімейний кодекс України від 10.01.2002 року № 2947-III [Електронний ресурс] - Режим доступу до ресурсу: https://zakon.rada.gov.ua/laws/ show/2947-14.

3. Ромовська 3.В. Сімейний кодекс України: Науково-практичний коментар. / 3.В. Ромовська. - К.: Правова єдність, 2009. - 432 с.

4. Закону України «Про загальнообов'язкове державне пенсійне страхування» від 09.07.2003 року № 1058-IV [Електронний ресурс] - Режим доступу до peсурсу: https://zakon.rada.gov.ua/laws/ show/1058-15.

5. Закону України «Про прожитковий мінімум» від 15.07.1999 року № 966-XIV [Електронний ресурс] - Режим доступу до ресурсу: https://zakon.rada.gov.ua/ laws/show/966-14.

6. Закону України «Про реабілітацію осіб з інвалідністю в Україні» від 06.10.2005 року № 2961-IV [Електронний ресурс] - Режим доступу до ресурсу: https://zakon.rada.gov.ua/ laws/show/2961-15.

7. Закон України «Про зайнятість населення» від 05.07.2012 року № 5067-VI [Електронний ресурс] - Режим доступу до ресурсу: https://zakon.rada.gov.ua/ laws/show/5067-17.

8. Постанова Пленуму Верховного Суду України «Про судову практику у справах про спадкування» від 30.05.2008 року № 7 [Електронний ресурс] - Режим доступу до ресурсу: https://zakon.rada.gov.ua/ laws/show/v0007700-08.

9. Закону України «Про основні засади соціального захисту ветеранів праці та 
інших громадян похилого віку в Україні» від 16.12.1993 року № 3721-XII [Електронний ресурс] - Режим доступу до ресурсу: https://zakon.rada.gov.ua/laws/ show/3721-12.
10.Постанова Верховного Суду у справі № 200/21452/15-ц [Електро- нний ресурс] - Режим доступу до pecypсу: http://reyestr.court.gov.ua/ Review/77361705.

\section{Lukianchuk O.I. Care of disabled, infirm parents: legislative consolidation of moral duty}

The purpose of this study is to find ways to put into practice a rule that reinforces the obligation of children to care for their parents. In order to achieve this goal, the following tasks are to be solved: establishing the essence of the child's duty to care for the parents, determining its features, explaining the circumstances and conditions under which the parents are entitled to recover the costs of providing care. The article analyzes the content of the constitutional obligation of a child, a grown daughter, a son to take care of their parents. The preconditions, which contributed to the legislative consolidation of this obligation, have been analyzed. The circle of persons who are obliged to take care of their parents have been determined. Due to the systematic analysis of the legislation, the legal definition of the state of frailty has been proposed. It has been established that the state of frailty coincides with the signs of a helpless state. The necessity to enshrine the definition of a state of frailty at the legislative level has been justified, which, in turn, corresponds to the signs of incapacity. It has been found that parents can theoretically stay in disabled homes, retirement homes, health care facilities, or other government or community facilities. If adult children do not participate in the custody of their parents, placed in these institutions, the latter have the right to sue the parents for forced parental alimony. A distinction between the responsibility of children to take care of their parents (Article 172 of the Civil Code of Ukraine), the obligation of a grown daughter, a son to share parents' additional expenses caused by serious illness, disability or frailty (Article 203 of the Family Code) and the right of parents who are seriously ill or disabled to collect money for their treatment and care from a child (minor), a daughter, a son has been determined (Article 206 of the UK Code). The grounds for the parents' right to collect money by court order for cost recovery connected with provision of care by the third parties have been defined. Particular attention has been paid to the institution of legal representation, since grown daughters and sons are empowered to seek protection of the rights and interests of their disabled, feeble parents as their legal representatives, without special powers. The problems of conflict of rules on this issue as well as the ways of its solution have been considered.

Key words: family law, duty to take care, care, assistance, incapacitated, a helpless state, frailty, disabled person, legal representative, old age, cost recovery, serious illness, injury, representation, money collection, maintenance, alimony. 